\title{
Is pulmonary embolism associated with pleural transudates, exudates, or both?
}

\author{
José M. Porcel ${ }^{1 *}$, Aureli Esquerda², Laura Porcel ${ }^{3}$, and Silvia Bielsa ${ }^{1}$ \\ ${ }^{1}$ Pleural Medicine Unit, Internal Medicine Service, Hospital Universitari Arnau de Vilanova, IRBLleida, Universitat de Lleida, Lleida; ${ }^{2}$ Clinical Analysis \\ Service, Hospital Universitari Arnau de Vilanova, Lleida; ${ }^{3}$ nternal Medicine Service, Hospital Universitario Príncipe de Asturias, Alcalá de Henares, \\ Madrid. Spain
}

\begin{abstract}
Introduction and objectives: Whether pleural effusions (PEs) secondary to pulmonary embolism can be exudative or transudative is controversial. This study aims to determine which type of effusion (exudate or transudate) is typically associated with pulmonary embolism, using Light's criteria as the discriminative gold standard. Methods: A retrospective analysis of all consecutive patients with pulmonary embolism subjected to a diagnostic thoracentesis over a 25-year period in a University Hospital was performed. Pleural fluid data were described in detail. Results: Seventy-one patients with pulmonary embolism-associated PEs comprised the study population. Pleural fluids were bloody in more than half the cases. The pleural fluid differential white blood cell count was variable; the predominant cells (>50\% of the total leukocytes) were lymphocytes in nearly two-thirds of the patients and neutrophils in about $30 \%$. A proportion of eosinophils $>10 \%$ was observed in $7 \%$ of the cases. All fluids were exudates, meeting either $3(78.2 \%), 2(12.7 \%)$, or just $1(9.1 \%)$ of the Light's criteria. Conclusion: The pleural fluid that accompanies pulmonary embolism is invariably an exudate.
\end{abstract}

Key words: Pleural effusion. Pulmonary embolism. Transudate. Exudate.

\section{Introduction}

Pulmonary embolism is a relatively infrequent cause of pleural effusions (PEs) but, at the same time, it is a disorder commonly overlooked during the work-up of undiagnosed effusions. In a series of 3077 patients with PEs who underwent thoracentesis, pulmonary embolism accounted for just $1.5 \%$ of the cases ${ }^{1}$. Paradoxically, PEs are observed in about one-third of patients with pulmonary embolism by chest radiograph, and half the cases when using computed tomography ${ }^{2}$. The fact that most of these PEs are small (and thus not amenable to thoracentesis) or discovered when the diagnosis of pulmonary embolism is already established (thus making unnecessary a diagnostic aspiration), explains the low prevalence of pulmonary embolism among the etiology of tapped PEs ${ }^{3}$.

Whether pulmonary embolism may generate transudates or exudates has long been a point of discussion, largely due to the unawareness of the exact pathophysiology of fluid formation in this condition. The aim of the current study was to define the transudative or exudative nature of PEs secondary to pulmonary embolism, using Light's criteria as the reference standard ${ }^{4}$, in the largest series published to date.

\section{Visual abstract available at https://www.spanishjmed.com/frame_esp.php?id=26}

\footnotetext{
Correspondence:

*José M. Porcel

E-mail: jporcelp@yahoo.es

Date of reception: $14-12-2020$

Date of acceptance: $28-12-2020$

DOI: 10.24875/SJMED.M21000006

Available online: 16-03-2021

Span J Med. 2021;1(1):21-25

www.spanishjmed.com

2696-5631 / @ 2020 Sociedad Española de Medicina Interna. Published by Permanyer. This is an open access article under the CC BY-NC-ND license (http://creativecommons.org/licenses/by-nc-nd/4.0/).
} 


\section{Methods}

We performed a retrospective analysis from a prospectively maintained database, which includes all consecutive patients with PEs who have undergone a diagnostic thoracentesis at the Arnau de Vilanova University Hospital (Lleida, Spain) for the past 25 years. Patients with a final diagnosis of PE secondary to pulmonary embolism were the focus of the current investigation. The study protocol was approved by the local ethics committee (CEIC No. 1965).

The diagnosis of pulmonary embolism was made radiographically by computed tomographic pulmonary angiography and, except in two patients with a history of hypersensitivity reaction to iodinated contrast agents who were diagnosed by using lower extremity compression ultrasonography with Doppler in the adequate clinical context. Attributing the PE to pulmonary embolism also required excluding other potential causes of fluid formation based on clinical data and pleural fluid analyses.

We recorded demographics, location, and size of PEs on chest radiographs, biochemistries of serum (i.e., protein, albumin, and lactate dehydrogenase $[\mathrm{LDH}]$ ) and pleural fluid (i.e., total and differential cell count, protein, $\mathrm{LDH}$, glucose, $\mathrm{pH}$, adenosine deaminase and, if available, C-reactive protein, cholesterol, albumin, carcinoembryonic antigen [CEA], carbohydrate antigen 15-3 [CA 15- ${ }^{3}$, and natriuretic peptides), time from symptom onset to thoracentesis, and elapsed time between the start of anticoagulation and pleural tapping.

Most thoracenteses were performed under ultrasound assistance. If the patient had been submitted to repeated thoracentesis, only the results of the first one were considered. All biochemical measurements of pleural fluid and serum were performed on selective, discrete multichannel analyzers using standard methodologies. Pleural fluid cell counts were carried out either manually in a Thoma counting chamber or using an automatic hematology analyzer. In our laboratory, the upper normal limit for serum LDH is $375 \mathrm{U} / \mathrm{L}$. Malignancy cutoff points used for pleural fluid CEA and CA $15-3$ were $45 \mathrm{ng} / \mathrm{mL}$ and $77 \mathrm{IU} / \mathrm{mL}$, respectively ${ }^{5}$. Pleural fluid levels of brain natriuretic peptide (BNP) $>115 \mathrm{pg} / \mathrm{mL}^{6}$ and of N-terminal pro-BNP > $1500 \mathrm{pg} / \mathrm{mL}^{7}$ are generally associated with heart failure. A serum-pleural fluid albumin gradient (serum albumin minus pleural fluid albumin) $>1.2 \mathrm{~g} / \mathrm{dL}$ or a serum-pleural fluid protein gradient $>3.1 \mathrm{~g} / \mathrm{dL}$ has long been proposed to indicate a likely transudate in the setting of clinically suspected cardiac effusions that meet Light's criteria for exudate ${ }^{8}$.

PEs were categorized as transudates or exudates using the criteria reported by Light et al. ${ }^{4}$, wherein exudative PEs are identified by the presence of one or more of the following findings, whereas a transudate has none: (1) pleural fluid protein divided by serum protein $>0.5$, (2) pleural fluid LDH divided by serum LDH $>0.6$, and (3) pleural fluid LDH more than two-thirds $(67 \%)$ of the upper normal limit for serum LDH (which in our study implies a pleural fluid LDH > $250 \mathrm{U} / \mathrm{L}$ ).

Descriptive statistics were used to summarize patient characteristics and pleural fluid findings. Data are presented as numbers (proportions) or median (interquartile range [IQR]) as appropriate. Between-group comparisons were assessed by means of the MannWhitney U-test. $p<0.05$ was considered statistically significant. Calculations were done using the SPSS version 24.0 statistical software.

\section{Results}

By November 2020, our database encompassed 5460 patients with PEs, of whom 71 (1.3\%) had pulmonary embolism. Partial data of 26 of these patients were already reported in a previous own study with different primary outcomes ${ }^{2}$.

The current study population comprised 45 (63.4\%) men and $26(36.6 \%)$ women, with a median age of 74 years (IQR 52-84 years, range 23-93 years). On chest radiographs, $\mathrm{PEs}$ were right sided $(34,48 \%)$, left sided $(29,41 \%)$, or bilateral $(8,11 \%)$, while occupying onethird or less of the hemithorax in $63(88.7 \%)$ cases.

In the subgroup of patients in whom electronic records were available $(n=31)$, the median lag time between symptoms onset and diagnostic thoracentesis was 9 days (IQR 6-12 days). At the time of thoracentesis, $14(45 \%)$ patients were receiving anticoagulant therapy and 12 (38.7\%) were on diuretics.

Pleural fluid biochemical data are presented in table 1 and their interpretation, according to widely accepted cutoff values, is shown in table 2. Pleural fluid cultures and cytological examinations were performed in 46 and 59 patients, respectively, with negative results in all cases. The pleural fluid red blood cell count was higher than $10,000 / \mu \mathrm{L}$, which usually corresponds with a bloody appearance, in $55.7 \%$ of the cases and surpassed 100,000 / $\mu \mathrm{L}$ in $6(8.6 \%)$. The differential white blood cell count revealed a predominance of lymphocytes (i.e., $>50 \%$ of the total leukocyte count) in about two-thirds of the cases, of neutrophils in nearly $30 \%$, and pleural eosinophilia 
Table 1. Pleural fluid findings in pulmonary embolism

\begin{tabular}{|c|c|c|}
\hline Pleural fluid parameter & No. of patients & Value, median (quartiles) \\
\hline Erythrocyte count, $\times \mu \mathrm{L}$ & 70 & $15,150(3028-38,800)$ \\
\hline Leukocytes, $\times \mu \mathrm{L}$ & 71 & $1639(900-4000)$ \\
\hline Polymorphonuclear cells, \% & 71 & $33(17-59)$ \\
\hline Eosinophils, \% & 71 & $15(9-43)$ \\
\hline Lymphocytes, \% & 71 & $63(36-83)$ \\
\hline Glucose, mg/dL & 70 & $109(92-129)$ \\
\hline $\mathrm{pH}$ & 65 & $7.47(7.40-7.50)$ \\
\hline Adenosine deaminase, $\mathrm{U} / \mathrm{L}$ & 70 & $15(8-23)$ \\
\hline Protein, $\mathrm{g} / \mathrm{dL}$ & 71 & $4.1(3.3-4.8)$ \\
\hline Pleural fluid to serum protein ratio & 65 & $0.65(0.59-0.72)$ \\
\hline Serum to pleural fluid protein gradient, $\mathrm{g} / \mathrm{dL}$ & 65 & $2.2(1.7-2.7)$ \\
\hline $\mathrm{LDH}, \mathrm{U} / \mathrm{L}$ & 70 & $428(287-707)$ \\
\hline Pleural fluid to serum LDH ratio & 56 & $1.29(0.85-2.64)$ \\
\hline Cholesterol, mg/dL & 29 & $70(56-101)$ \\
\hline Albumin, $\mathrm{g} / \mathrm{dL}$ & 22 & $2.3(1.7-2.6)$ \\
\hline Serum to pleural fluid albumin gradient, $\mathrm{g} / \mathrm{dL}$ & 21 & $1.0(0.6-1.2)$ \\
\hline C-reactive protein, $\mathrm{mg} / \mathrm{L}$ & 30 & $31(17-71)$ \\
\hline CEA, ng/mL & 40 & $1.4(0.9-2.2)$ \\
\hline CA $15-3, \mathrm{IU} / \mathrm{mL}$ & 35 & $14.6(10.1-20.1)$ \\
\hline BNP, pg/mL & 12 & $83(34-104)$ \\
\hline NT-pro-BNP, pg/mL & 25 & $564(280-1778)$ \\
\hline
\end{tabular}

BNP: brain natriuretic peptide; CA 15-3: carbohydrate antigen 15-3; CEA: carcinoembryonic antigen; LDH: lactate dehydrogenase; NT-pro-BNP: N-terminal pro-BNP.

(i.e., $>10 \%$ of eosinophils) in $7 \%$. The discovery of predominantly neutrophilic or lymphocytic fluids was unrelated to symptom duration until the thoracentesis (median of 9 days when polymorphonuclear leukocytes predominated vs. 8.5 days for lymphocytic effusions, $p=0.451$ ). No patient exhibited elevated adenosine deaminase levels, marked pleural fluid acidosis (i.e., $\mathrm{pH}<7.20$ ). or high concentrations of classical tumor markers. Raised natriuretic peptide levels were observed in some of the few pleural fluids in which they could be measured.

PEs from all 71 patients met Light's criteria for exudates. In particular, of 55 patients for whom all three Light's items were available, one criterion was fulfilled by $5(9.1 \%)$ patients, two criteria by $7(12.7 \%)$, and three criteria by 43 (78.2\%). In addition, $85.7 \%$ and $92.3 \%$ of subjects had serum to pleural fluid albumin and protein gradients which were consistent with exudates, respectively.

\section{Discussion}

The present study supports the uniform exudative nature of all PEs secondary to pulmonary embolism. This challenge what has been traditionally taught, namely, that pulmonary embolism-associated PEs may be either an exudate or a transudate. In fact, the concept that pleural fluids in this condition might, although infrequently, have transudative characteristics is still reflected today in time-honored textbooks of Internal Medicine $^{9,10}$, and even recent reviews in top medical journals ${ }^{11}$.

Confusion about the precise exudate-transudate classification of these PEs stems from a report dating back to 1976 , in which $7(27 \%)$ of 26 pleural fluids associated with pulmonary embolism were labeled as transudates ${ }^{12}$. However, the criteria used to define exudates (and therefore 
Table 2. Pleural fluid characteristics according to widely accepted cutoff points

\begin{tabular}{|c|c|c|}
\hline Pleural fluid parameter & No. of patients & No. (\%) \\
\hline Erythrocytes $\geq 10,000 / \mu \mathrm{L}$ & 70 & $39(55.7)$ \\
\hline Neutrophils $>50 \%$ & 71 & $21(29.6)$ \\
\hline Eosinophils $>10 \%$ & 71 & $5(7)$ \\
\hline Lymphocytes $>50 \%$ & 71 & $46(64.8)$ \\
\hline Glucose $\leq 60 \mathrm{mg} / \mathrm{L}$ & 70 & $1(1.4)$ \\
\hline $\mathrm{pH} \leq 7.20$ & 65 & $0(0)$ \\
\hline Adenosine deaminase $\geq 35 \mathrm{U} / \mathrm{L}$ & 70 & $0(0)$ \\
\hline Protein $\geq 3 \mathrm{~g} / \mathrm{dL}$ & 71 & $60(84.5)$ \\
\hline Pleural to serum protein ratio $>0.5$ & 65 & $57(87.7)$ \\
\hline Serum to pleural fluid protein gradient $\leq 3.1 \mathrm{~g} / \mathrm{dL}$ & 65 & $60(92.3)$ \\
\hline $\mathrm{LDH}>250 \mathrm{U} / \mathrm{L}$ & 70 & $58(82.8)$ \\
\hline Pleural fluid to serum LDH ratio $>0.6$ & 56 & $52(92.8)$ \\
\hline Cholesterol $\geq 45 \mathrm{mg} / \mathrm{dL}$ & 29 & $27(93)$ \\
\hline Serum to pleural fluid albumin gradient $\leq 1.2 \mathrm{~g} / \mathrm{dL}$ & 21 & $18(85.7)$ \\
\hline CEA $>45 \mathrm{ng} / \mathrm{mL}$ & 40 & $0(0)$ \\
\hline CA $15-3>77 \mathrm{IU} / \mathrm{mL}$ & 35 & $0(0)$ \\
\hline BNP $>115 \mathrm{pg} / \mathrm{mL}$ & 12 & $1(8.3)$ \\
\hline NT-pro-BNP > 1500 pg/mL & 25 & 6 (24) \\
\hline
\end{tabular}

BNP: brain natriuretic peptide; CA 15-3: carbohydrate antigen 15-3; CEA: carcinoembryonic antigen; LDH: lactate dehydrogenase; NT-pro-BNP: N-terminal pro-BNP.

transudates) were not those reported by Light 4 years earlier, which were not yet universally accepted, but rather the pleural fluid concentrations of proteins $(>3 \mathrm{~g} / \mathrm{dL}$ ) or LDH (> 200 U/L). Notably, pleural fluid LDH was only measured in $12(46 \%)$ patients ${ }^{12}$. It should be stressed that the criteria reported by Light et al. 49 years ago ${ }^{4}$ to separate exudates from transudates still prevail. This is because they are stringent and classifies virtually all exudates correctly (sensitivity $98 \%$ ); even though they do misclassify about $25 \%$ of transudates as exudates, usually by a small margin ${ }^{13}$. Therefore, the application of alternative and less sensitive criteria for the identification of an exudate, as conducted in the study of Bynum and Wilson ${ }^{12}$, and two subsequent ones ${ }^{14,15}$, may miscategorize some cases. In fact, the sum of all studies, including the present one, where Light's criteria were applied demonstrates that all 142 patients with pulmonary embolism who were evaluated had pleural exudates (Table 3).

The terms transudate and exudate reflect the pathophysiological mechanism of pleural fluid formation. Transudates derive from imbalances in hydrostatic and oncotic forces over a structurally intact pleural surface, whereas exudates accumulate because of local factors affecting the pleura, such as increased capillary permeability and/or impaired lymphatic drainage resulting from many inflammatory and malignant causes. Since all pulmonary embolism associated PEs are exudates, it is presumed that increased permeability of pulmonary capillaries, probably related to the release of inflammatory mediators from the platelet-rich thrombi (e.g., vascular endothelial growth factor), is the most plausible mechanism by which pulmonary embolism produces $\mathrm{PEs}^{19}$. The right ventricular dysfunction that may accompany acute pulmonary embolism may account for the elevation of natriuretic peptides in the pleural fluid of some of these. Nearly $39 \%$ of patients were on diuretics at the time of thoracentesis, as now stated in Results.

This study is limited by its retrospective design and small sample size. However, thoracentesis is rarely attempted in the setting of a confirmed pulmonary embolism unless the PE is increasing in size and it is needed to exclude a hemothorax, or the patient is 
Table 3. Studies that have evaluated the categorization of pulmonary embolism-associated effusions as transudates or exudates

\begin{tabular}{|l|c|l|c|}
\hline Study & No. of patients & Criteria for exudates & No. (\%) of exudative effusions \\
\hline Bynum and Wilson, 1976 ${ }^{12}$ & 26 & $\begin{array}{l}\text { PF protein > 3 g/dL or } \\
\text { PF LDH > 200 U/L }\end{array}$ & $19(73)$ \\
\hline Romero-Candeira et al., 2002 & & Light's criteria & $60(100)$ \\
\hline Erkan et al., 2004 & 60 & Light's criteria & $5(100)$ \\
\hline Sandevski et al., 2012 & 5 & LDH fluid to serum ratio > 0.6 & $30(97)$ \\
\hline Choi et al., 2017 & 31 & Not specified & $12(92)$ \\
\hline Panjwani et al., 201918 & 13 & Light's criteria & $6(100)$ \\
\hline Current study, 2021* & 6 & Light's criteria & $71(100)$ \\
\hline Total & 71 & Light's criteria & $142(100)$ \\
\hline
\end{tabular}

*This series includes data of 26 patients from a previous own publication ${ }^{2}$

LDH: lactate dehydrogenase; PF: pleural fluid.

persistently febrile and it is needed to exclude a pleural infection.

\section{Conclusion}

In summary, although pulmonary embolism associated PEs were previously sometimes thought to be transudates, the few exudate-transudate studies that have used Light's standard criteria ${ }^{4}$ conclude that all are exudates.

\section{Funding}

This research received no specific grant from any funding agency in the public, commercial or not-for profit sectors.

\section{Conflicts of interest}

The authors declare that they have no conflicts of interest.

\section{Ethical disclosures}

Protection of human and animal subjects. The authors declare that the procedures followed were in accordance with the regulations of the relevant clinical research ethics committee and with those of the Code of Ethics of the World Medical Association (Declaration of Helsinki).

Confidentiality of data. The authors declare that they have followed the protocols of their work center on the publication of patient data.

Right to privacy and informed consent. The authors declare that no patient data appear in this article.

\section{References}

1. Porcel JM, Esquerda A, Vives M, Bielsa S. Etiology of pleural effusions: analysis of more than 3,000 consecutive thoracenteses. Arch Bronconeumol. 2014;50:161-5

2. Porcel JM, Madroñero AB, Pardina M, Vives M, Esquerda A, Light RW. Analysis of pleural effusions in acute pulmonary embolism: radiological and pleural fluid data from 230 patients. Respirology. 2007;12:234-9.

3. Porcel JM, Light RW. Pleural effusions due to pulmonary embolism. Curr Opin Pulm Med. 2008;14:337-42.

4. Light RW, Macgregor MI, Luchsinger PC, Ball WC Jr. Pleural effusions: the diagnostic separation of transudates and exudates. Ann Intern Med. 1972;77:507-13.

5. Porcel JM, Civit C, Esquerda A, Salud A, Bielsa S. Utility of CEA and CA 15-3 measurements in non-purulent pleural exudates in the diagnosis of malignancy: a single-center experience. Arch Bronconeumol. 2017;53:427-31.

6. Porcel JM, Martínez-Alonso M, Cao G, Bielsa S, Sopena A, Esquerda A. Biomarkers of heart failure in pleural fluid. Chest. 2009;136:671-7.

7. Porcel JM, Vives M, Cao G, Esquerda A, Rubio M, Rivas MC. Measurement of pro-brain natriuretic peptide in pleural fluid for the diagnosis of pleural effusions due to heart failure. Am J Med. 2004;116:417-20.

8. Porcel JM, Ferreiro L, Civit C, Valdés L, Esquerda A, Light RW, et al. Development and validation of a scoring system for the identification of pleural exudates of cardiac origin. Eur J Intern Med. 2018;50:60-4.

9. Rodriguez-Panadero F. Enfermedades de la pleura. In: Farreras-Rozman Medicina Interna. 19 ${ }^{\text {th }}$ ed. Barcelona: Elsevier; 2020. p. 745-56.

10. Light RW. Disorders of the pleura. In: Jameson JL, Fauci AS, Kasper DL, Hauser SL, Longo DL, Loscalzo J, editors. Harrison's Principles of Internal Medicine. $20^{\text {th }}$ ed. New York: McGraw-Hill; 2018. p. 2006-9.

11. Feller-Kopman D, Light R. Pleural disease. N Engl J Med. 2018;378:1754

12. Bynum LJ, Wilson JE $3^{\text {rd }}$. Characteristics of pleural effusions associated with pulmonary embolism. Arch Intern Med. 1976;136:159-62.

13. Porcel JM, Light RW. Pleural effusions. Dis Mon. 2013:59:29-57.

14. Sandevski A, Kaeva BJ, Gligorovski L, Simonovska L, Sandevska E. Frequency and characteristics of pleural effusions in pulmonary embolism. Prilozi. 2012;33:93-104.

15. Choi SH, Cha SI, Shin KM, Lim JK, Yoo SS, Lee SY, et al. Clinical relevance of pleural effusion in patients with pulmonary embolism. Respiration. 2017:93:271-8.

16. Candeira SR, Blasco LH, Soler MJ, Muñoz A, Aranda I. Biochemical and cytologic characteristics of pleural effusions secondary to pulmonary embolism. Chest. 2002;12:465-9.

17. Erkan L, Fýndýk S, Uzun O, Atýcý AG, Light RW. A new radiologic appearance of pulmonary thromboembolism: multiloculated pleural effusions. Chest. 2004;126:298-302.

18. Panjwani A, Zaid T, Alawi S, Al Shehabi D, Abdulkarim ES. Pleural effusion in acute pulmonary embolism in Bahrain: radiological and pleural fluid characteristics. Lung India. 2019;36:112-7.

19. Light RW. Pleural effusion in pulmonary embolism. Semin Respir Crit Care Med. 2010;31:716-22. 